\title{
REKAYASA MEDIA TANAM MENGGUNAKAN TONGKOL JAGUNG DAN DEDAK TERHADAP PERTUMBUHAN DAN PRODUKSI JAMUR TIRAM (Pleurotus ostreatus)
}

\author{
Kartika Oktasari 1), Husain Syam²), Jamaluddin 2) \\ ${ }^{1}$ Alumni Program Studi Pendidikan Teknologi Pertanian \\ ${ }^{2}$ dan ${ }^{3}$ Dosen PTP FT UNM
}

\begin{abstract}
The cultivation of oyster mushroom (Pleorotus ostreatus) is not many expanded yet in Indonesia, either the exertion chance or the consumtion fulfillment of society. The objective research is to know the growt, production, storability, and the protein content degree of oyster mushroom on the basic media of sawdust were mixed with some compositions of corn cob flour brand. The research was arranged on completely random design with treatments mixture of sawdust from jati wood with corn cob $(15 \%, 25 \%, 35 \%)$ and brand $(15 \%, 25 \%, 35 \%)$. Oyster mushroom growth were observed at seven days after inoculation. The data were analyzed by of Varian Analysis (ANOVA) and continued with Duncant Multiple Range Test (DMRT) on 5\% level.Result showed that corn cob and brand were effective admixture to enhance oyster mushroom production. The optimal growth, production, and protein content is found in the mixture of brand media with concentration $35 \%$, while for corn cob media with concentration $25 \%$ But for the storability of oyster mushroom the result showed that the corn cob and brand has not a significant influence.
\end{abstract}

Keywords: Engineering, Growing Media, growth, production, and Oyster Mushroom.

\section{PENDAHULUAN}

Jamur tiram adalah jenis jamur kayu yang memiliki kandungan nutrisi lebih tinggi dibandingkan dengan jenis jamur kayu lainnya. Komposisi dan kandungan nutrisi jamur tiram setiap 100 gram yaitu kalori 367 kal; protein $20,4 \%$; karbohidrat $56,6 \%$; lemak $2,2 \%$; thiamin $0,20 \mathrm{mg}$; riboflavin 4,9 mg; niacin 77,2 mg; kalsium 314 mg; kalium 3.793 mg; fosfor $717 \mathrm{mg}$; natrium $837 \mathrm{mg}$; besi 18,2 mg. Jamur tiram juga mengandung 18 asam amino yang dibutuhkan oleh tubuh manusia dan tidak mengandung kolesterol (Djarijah, 2010). Seiring dengan popularitas serta memasyarakatnya jamur tiram sebagai obat dan bahan makanan lezat dan bergizi, maka permintaan konsumen dan pasar jamur tiram di berbagai daerah terus meningkat.
Jamur tiram dalam bahasa Yunani disebut Pleurotus, artinya bentuk samping atau posisi menyamping antara tangkai dengan tudung. Sedangkan sebutan nama tiram, karena bentuk atau tubuh buahnya menyerupai kulit tiram atau cangkang tiram. Jamur tiram (Pleurotus ostreatus) merupakan jenis jamur kayu karena jamur ini banyak tumbuh pada media kayu yang sudah lapuk. Jamur tiram tidak mempunyai klorofil, sehingga jamur tidak dapat menyediakan makanan sendiri dengan cara fotosintesis seperti pada tanaman yang berklorofil, oleh karena itu jamur tiram mengambil zat-zat makanan yang sudah jadi yang dibuat atau dihasilkan oleh organisme lain untuk kebutuhan hidupnya. Karena ketergantungannya terhadap organism lainnya inilah maka 
jamur tiram digolongkan sebagai tanaman heterotrofik.

Saat ini jamur tiram putih (Pleurotus ostreatus) sudah mulai dibudidayakan,yaitu dengan menggunakan limbah pertanian sebagai media tumbuhnya. Dalam pembuatan media tanam jamur tiram putih (Pleurotus ostreatus) terdiri dari bahan baku dan bahan tambahan. Bahan baku berupa limbah serbuk kayu gergaji, sebagai bahan tambahan pada umumnya berupa dedak dan kapur (CaCO3). Penambahan dedak pada media tanam berperan dalam perkembangan miselium dan pertumbuhan tubuh buah jamur (Abdul, 2013), karena mengandung vitamin, karbohidrat, lemak dan protein. Jamur tiram termasuk jenis jamur perombak kayu yang dapat tumbuh pada berbagai media seperti serbuk gergaji, jerami, sekam, limbah kapas, limbah daun teh, klobot jagung, ampas tebu, limbah kertas, dan limbah pertanian maupun industri lain yang mengandung bahan lignoselulosa (Sumarsih, 2010).

Seiring dengan pertambahan populasi dan aktivitas manusia serta produksi limbah yang semakin meningkat oleh adanya home industri, menyebabkan diperlukannya penanganan limbah secara khusus agar tidak terjadi timbunan sampah yang meninggi. Penanganan masalah limbah terutama pada limbah tongkol jagung yang di hasilkan oleh para pengusaha pakan ternak salah satunya, yaitu dengan memanfaatkan limbah tersebut sebagai media pertumbuhan jamur tiram putih (Pleurotus ostreatus). Bahan-bahan tersebut ketersediaannya sangat melimpah dan belum banyak dimanfaatkan di Indonesia sehingga dapat dijadikan sebagai media tanam dalam budidaya jamur tiram. Pemanfaatan jenis-jenis limbah untuk budidaya jamur tiram akan membantu memecahkan masalah penumpukan limbah, menciptakan lapangan kerja baru serta meningkatkan sumber pendapatan petani dan pengusaha. Tongkol jagung dapat dimanfaatkan sebagai media tanam jamur tiram karena kandungan karbohidrat dan proteinnya yang tinggi. Penelitian ini bertujuan untuk mengetahui pengaruh pemberian campuran tepung tongkol jagung dan dedak terhadap pertumbuhan, produksi, daya simpan, dan kadar protein jamur tiram.

\section{METODE PENELITIAN}

Jenis penelitian ini merupakan penelitian eksperimen. Alat yang digunakan dalam penelitian ini adalah, plastik PP (polypropilen), cincin paralon, oven, Bahan yang digunakan dalam penelitian ini ialah bibit jamur tiram putih (Pleurotus ostreatus), serbuk gergaji kayu jati, dedak, tongkol jagung, gypsum dan kapur.

Perlakuan dalam penelitian ini terdiri dari media serbuk kayu 100\% (kontrol), campuran serbuk kayu dan dedak dengan perbandingan masingmasing $85 \%: 15 \%, \quad 75 \%: 25 \%$, dan 65\%:35\%, campuran serbuk kayu dan tepung tongkol jagung dengan perbandingan masing-masing 85\%:15\%, 75\%:25\%, dan 65\%:35\%. Penelitian ini setiap perlakuan diulang 3 kali sehingga didapatkan 21 unit eksperimen.

Langkah persiapan meliputi pembuatan mediabaglog, yaitu media tanam berupa serbuk kayu dicampur dengan media tambahan berupa dedak, tepung tongkol jagung, kapur, dan gypsum. Media ini di masukkan ke dalam plastik Polypropilene hingga $1,2 \mathrm{~kg}$, kemudian mulut baglog diberi cincin plastik dan disumbat dengan kapas. 
Media disterilkan dengan menggunakan oven selama 6 jam. Inokulasijamur Pleurotusostreatus dilakukan dengan menggunakan bibit jamur F2. Pengamatan dilakukan dengan mengukur panjang miselium jamur Tiram Putih (Pleurotus ostreatus) dengan menggunakan kertas grafik yang ditempelkan pada media tanam dan dilakukan pengamatan tiap tiga hari sekali sampai miselium memenuhi baglog. Baglog yang sudah dipenuhi miselium dipindahkan ke ruang perawatan lalu dibuka mulut baglog sebagai tempat munculnya tubuh buah jamur. Tubuh buah jamur yang siap panen dicabut dan dibersihkan dari media tanam dan kemudian ditimbang berat basahnya dengan menggunakan timbangan digital. Selanjutnya dihitung jumlah badan buah jamur pada tiap rumpun media tanam. Pengamatan terhadap daya simpan jamur dilakukan di ruang terbuka dengan suhu kamar tanpa pengemasan. Tahap pengamatan terakhir adalah pengujian analisis kadar protein jamur yang dilakukan di Balai Besar Perindustrian Hasil Perkebunan.

Data yang diperoleh dari penelitian ini berupa kecepatan pertumbuhan miselium, tubuh buah jamur, produksi, daya simpan, dan kadar protein Tiram Putih (Pleurotus ostreatus), selanjutnya data tersebut di analisis dengan menggunakan analisis varian (ANOVA) satu arah dan dilanjutkan dengan uji Duncan Multiple Range Test (DMRT).

\section{HASIL DAN PEMBAHASAN}

\section{A. Pertumbuhan}

\section{Panjang Miselium}

Jamur tiram putih merupakan tanaman yang tidak memiliki klorofil tetapi memiliki spora yang merupakan sel yang saling bersambung membentuk benang bersekat yang disebut hifa. Hifa yang menyatu akan membentuk suatu jaringan yang disebut miselium. Fungsi dari miselium adalah menyerap air, nutrisi dan bahan organik dari media tanam untuk digunakan dalam pertumbuhan dan perkembangan jamur tiram putih. Pengamatan terhadap panjang miselium dilakukan pada 7-31 hari setelah inokulasi (HSI) dengan interval 3 hari. Pengamatan terhadap panjang miselium dilakukan dengan mengukur panjang miselium mulai dari media tanam yang paling atas atau tepat di bagian bawah cincin hingga memenuhi keseluruhan media tanam yang mempunyai rata-rata ketinggian sebesar $\quad 19-20$

$\mathrm{cm}$ 
Tabel 1

Rerata Panjang Miselium 7-31 Hari Setelah Inokuasi

\begin{tabular}{|c|c|c|c|c|c|c|c|c|c|}
\hline \multirow[b]{2}{*}{ Perlakuan } & \multicolumn{9}{|c|}{ Hari Setelah Inokulasi (HSI) } \\
\hline & $\begin{array}{c}7 \\
\mathrm{HSI}\end{array}$ & $\begin{array}{c}10 \\
\mathrm{HSI}\end{array}$ & $\begin{array}{c}13 \\
\text { HIS }\end{array}$ & $\begin{array}{c}16 \\
\mathrm{HSI}\end{array}$ & $\begin{array}{c}19 \\
\text { HSI }\end{array}$ & $\begin{array}{c}22 \\
\mathrm{HSI}\end{array}$ & $\begin{array}{c}25 \\
\mathrm{HSI}\end{array}$ & $\begin{array}{c}28 \\
\mathrm{HSI}\end{array}$ & $\begin{array}{c}31 \\
\mathrm{HSI}\end{array}$ \\
\hline $100 \%$ serbuk kayu & $1,4 a$ & $3,3 a$ & $5,4 a$ & $7,2 a$ & $9,3 a$ & $11,2 \mathrm{a}$ & $13,3 a$ & $15,4 a$ & $17,5 a$ \\
\hline $\begin{array}{l}\text { Serbuk kayu } 85 \% \text { : dedak } \\
15 \%\end{array}$ & $1,5 a b$ & $3,5 a b$ & $5,8 b$ & $7,5 b$ & $9,6 b$ & $11,5 a b$ & $13,7 b$ & $16,1 b$ & $18,0 b$ \\
\hline $\begin{array}{l}\text { Serbuk kayu } 75 \% \text { : dedak } \\
25 \%\end{array}$ & $2,0 \mathrm{c}$ & $3,7 a b$ & $6,3 c$ & $7,8 b$ & $10,0 \mathrm{c}$ & $11,7 b$ & $14,1 \mathrm{c}$ & $16,3 b c$ & $18,3 b c$ \\
\hline $\begin{array}{l}\text { Serbuk kayu } 65 \% \text { : dedak } \\
35 \%\end{array}$ & $2,3 \mathrm{~cd}$ & $3,8 \mathrm{bc}$ & $6,5 c$ & $8,2 \mathrm{c}$ & $10,5 d$ & $12,2 \mathrm{c}$ & $14,6 \mathrm{~d}$ & $16,7 \mathrm{~cd}$ & $18,5 c$ \\
\hline $\begin{array}{l}\text { Serbuk kayu } 85 \% \text { : tepung } \\
\text { tongkol jagung } 15 \%\end{array}$ & $2,5 d$ & $4,2 \mathrm{~cd}$ & $7,0 \mathrm{~d}$ & $8,5 \mathrm{~cd}$ & $10,7 \mathrm{de}$ & $12,6 \mathrm{c}$ & $15,0 \mathrm{e}$ & $17,0 \mathrm{de}$ & $19,0 d$ \\
\hline $\begin{array}{l}\text { Serbuk kayu } 75 \% \text { : tepung } \\
\text { tongkol jagung } 25 \%\end{array}$ & $2,7 d$ & $4,6 d$ & $7,3 d$ & $9,0 d$ & $11,4 \mathrm{ef}$ & $13,2 \mathrm{de}$ & 15,3 ef & 17,4 ef & $19,5 \mathrm{de}$ \\
\hline $\begin{array}{l}\text { Serbuk kayu } 65 \% \text { : tepung } \\
\text { tongkol jagung } 15 \%\end{array}$ & $2,6 d$ & $4,4 d$ & $7,3 \mathrm{e}$ & $8,6 e$ & $11,0 f$ & $13,0 \mathrm{e}$ & $15,3 f$ & $17,2 f$ & $19,3 e$ \\
\hline
\end{tabular}

Secara umum, penambahan media campuran dedak dan tepung tongkol jagung memberikan respon yang sangat nyata terhadap pertumbuhan dan hasil produksi jamur tiram putih. Berdasarkan hasil analisis sidik ragam seperti yang ditunjukkan pada Tabel 1 diketahui bahwa penambahan beberapa konsentrasi dedak dan tepung tongkol jagung memiliki hasil yang berbeda terhadap panjang miselium jamur. Perlakuan pemberian dedak yang memiliki rata-rata panjang miselium jamur tertinggi adalah pada kosentrasi $35 \%$ yaitu $18,56 \mathrm{~cm}$ sementara untuk pemberian tepung tongkol jagung yang memiliki rata-rata panjang miselium jamur tertinggi adalah pada kosentrasi $25 \%$ yaitu $19,53 \mathrm{~cm}$, hal ini disebabkan karena kandungan gizi pada tepung tongkol jagung yang lebih tinggi dibandingkan dengan kandungan gizi dari dedak salah satunya adalah karbohidrat. Gunawan (2005) menjelaskan bahwa semua unsur yang terdapat dalam karbon sepertimonosakarida, polisakarida, asam organik, asam amino, alkohol, lemak, selulosa dan lignin dapat digunakan oleh jamur untuk memenuhi kebutuhan energi dalam pertumbuhan dan perkembangan jamur. Fungsi karbohidrat bagi jamur yaitu dioksidasi sebagai sumber utama energi kimia yang tersedia untuk sel dalam bentuk ATP 26 dan menyediakan karbon yang dibutuhkan untuk asimilasi karbohidrat, lipid, asam amino, serta unsur organik lainnya (Tampubolon, 2010:11). Selain itu, lebih lambatnya umur miselium terbentuk pada konsentrasi $35 \%$ disebabkan tongkol jagung mengandung zat ekstraktif. Zat ekstraktif merupakan komponen non struktural yang banyak terdapat pada kayu sehingga jika komposisi tongkol jagung lebih dari $25 \%$ zat ekstraktif yang berupa lignin ini akan menghambat pertumbuhan miselium jamur.

Faktor utama dalam budidaya jamur tiram adalah ketersediaan nutrisi pada media yang cukup. Komposisi dalam media tumbuh ikut menentukan 
ketersediaan nutrisi bagi jamur, semakin komplek bahan yang digunakan maka semakin banyak nutrisi yang dihasilkan.

\section{Jumlah Badan Jamur}

Hasil pengujian lanjut DMRT yang ditunjukkan oleh Tabel 2 memperlihatkan bahwa pemberian tepung tongkol jagung pada konsentrasi $25 \%$ merupakan perlakuan terbaik. Hal ini memperlihatkan bahwa untuk pemberian campuran tepung tongkol jagung pada konsentrasi $25 \%$ sudah mampu menyediakan nutrisi yang dibutuhkan jamur tiram untuk proses pertumbuhannya dimana hasil pengamatan menunjukkan bahwa pada konsentrasi $35 \%$ pertumbuhan dan produksi jamur tiram tidak jauh berbeda pada konsentrasi $25 \%$.

Hasil pengamatan tersebut didukung oleh penelitian yang dilakukan Suharnowo (2012) dengan menggunakan limbah kulit ari biji kedelai yang menyatakan bahwa pemberian campuran media tanam yang mengandung karbohidrat dalam jumlah yang besar yaitu di atas $80 \%$ maka pemberian campuran media pada komposisi $20 \%$ sudah mampu meningkatkan produktivitas jamur tiram. Berdasarkan hasil tersebut juga menunjukkan bahwa semakin baik nutrisi yang terkandung dalam media tanam maka pertumbuhan jamur pun semakin baik.

Adapun nutrisi atau hara yang dibutuhkan jamur tiram untuk menunjang proses pertumbuhannya yaitu: (a)Karbon. Karbon (C) bersumber dari karbohidrat sebagai unsur dasar pembentukan sel. Sumber karbon diperoleh dalam bentuk monosakarida, polisakarida, selulosa dan lignin (kayu). (b) Nitrogen. Nitrogen diperlukan untuk pembentukan protein, lemak dan berbagai unsur lainnya. Nitrogen juga berguna untuk mempercepat pertumbuhan. (c) Vitamin. Vitamin berfungsi sebagai bahan tambahan atau suplemen sehingga pertumbuhan jamur menjadi lebih baik. Vitamin yang dibutuhkan oleh jamur yaitu vitamin B1 dan B12.

Tabel 2

Rerata Jumlah Badan Jamur

\begin{tabular}{|c|c|}
\hline Perlakuan & $\begin{array}{l}\text { Rata- } \\
\text { Rata }\end{array}$ \\
\hline $100 \%$ serbuk kayu & $7,0 \mathrm{a}$ \\
\hline Serbuk kayu $85 \%$ : dedak $15 \%$ & $9,6 b$ \\
\hline Serbuk kayu $75 \%$ : dedak $25 \%$ & $10,3 b$ \\
\hline Serbuk kayu $65 \%$ : dedak $35 \%$ & $12,0 \mathrm{bc}$ \\
\hline $\begin{array}{l}\text { Serbuk kayu } 85 \% \text { : tepung tongkol } \\
\text { jagung } 15 \%\end{array}$ & $13,6 \mathrm{~cd}$ \\
\hline $\begin{array}{l}\text { Serbuk kayu } 75 \% \text { : tepung tongkol } \\
\text { jagung } 15 \%\end{array}$ & $15,6 d$ \\
\hline $\begin{array}{l}\text { Serbuk kayu } 65 \% \text { : tepung tongkol } \\
\text { jagung } 35 \%\end{array}$ & $14,3 d$ \\
\hline $\begin{array}{l}\text { Murbandono } \\
\text { menyatakan bahwa semakin } \\
\text { nutrisi yang diperoleh } \\
\text { pertumbuhan miselium akan } \\
\text { cepat. Banyaknya miselium yang } \\
\text { akan mempengaruhi banyakny } \\
\text { buah yang kemudian berpengar } \\
\text { berat segar total tubuh buah jamb }\end{array}$ & $\begin{array}{l}12: 52) \\
\text { anyak } \\
\text { maka } \\
\text { makin } \\
\text { umbuh } \\
\text { tubuh } \\
\text { pada } \\
\text { tiram. }\end{array}$ \\
\hline
\end{tabular}

\section{B. Produksi}

Berdasarkan analisis ragam seperti yang diperlihatkan pada Tabel 3 diperoleh data bahwa terjadi beda nyata antar perlakuan. Data saat munculnya pin head pertama ini sangat berhubungan dengan hasil pengamatan panjang miselium. Perlakuan dengan panjang miselium yang lebih panjang yaitu perlakuan pemberian tepung tongkol jagung dengan komposisi $25 \%$ yaitu $19,19 \mathrm{~cm}$ maka pin head akan 
muncul lebih cepat yaitu pada $44 \mathrm{HSI}$. Sebaliknya perlakuan dengan miselium paling pendek pada akhir pengamatan yaitu perlakuan tanpa pemberian dedak dan tepung tongkol jagung sepanjang $10,35 \mathrm{~cm}$ memiliki saat muncul pin head pertama yang lebih lambat yaitu $47 \mathrm{HSI}$. Hal ini disebabkan karena miselium yang telah memenuhi media tanam tersebut akan mensuplai nutrisi lebih awal dibandingkan dengan media tanam lainnya yang miseliumnya belum penuh.

Tabel 3

Rerata Produksi Jamur

\begin{tabular}{lc}
\hline \multicolumn{1}{c}{ Perlakuan } & $\begin{array}{c}\text { Rata- } \\
\text { Rata }\end{array}$ \\
\hline 100\% serbuk kayu & $88,9 \mathrm{a}$ \\
Serbuk kayu 85\% : dedak 15\% & $95,2 \mathrm{~b}$ \\
Serbuk kayu 75\% : dedak 25\% & $103,7 \mathrm{c}$ \\
$\begin{array}{l}\text { Serbuk kayu 65\% : dedak 35\% } \\
\text { Serbuk kayu 85\% : tepung tongkol }\end{array}$ & $110,8 \mathrm{~d}$ \\
jagung 15\% & $116,0 \mathrm{e}$ \\
$\begin{array}{l}\text { Serbuk kayu 75\% : tepung tongkol } \\
\text { jagung 15\% }\end{array}$ & $130,7 \mathrm{f}$ \\
$\begin{array}{l}\text { Serbuk kayu 65\% : tepung tongkol } \\
\text { jagung 35\% }\end{array}$ & $117,9 \mathrm{e}$ \\
\hline
\end{tabular}

Perlakuan pemberian tepung tongkol jagung yang memiliki rerata produksi tertinggi adalah pada komposisi $25 \%$ yaitu $130,7 \mathrm{~g}$, sementara untuk perlakuan pemberian dedak yang memiliki rerata produksi tertinggi adalah pada komposisi $35 \%$ yaitu $110,8 \mathrm{~g}$. Hal ini disebabkan karena jamur membutuhkan sumber nutrisi dalam bentuk unsur hara seperti nitrogen, fosfor, belerang, karbon (Suriawiria, 2010:23). Nutrisi tambahan tersebut terdapat dalam tongkol jagung dengan jumlah yang lebih banyak daripada dedak.

\section{Daya Simpan}

Pemberian dedak dan tepung tongkol jagung berdasarkan hasil analisis sidik ragam pada Tabel 4 menunjukkan bahwa perlakuan tidak memberikan pengaruh yang nyata. Lama penyimpanan jamur tiram rata-rata hanya bertahan antara 28-29 jam. Hal ini disebabkan karena kandungan dari dedak dan tongkol jagung hanya dimanfaatkan jamur untuk proses pertumbuhan dan perkembangan miselium. Dugaan ini diperkuat dengan permyataan Welem (2014) yang mengatakan bahwa jamur tiram tidak memiliki daya tahan yang cukup lama untuk disimpan dalam suhu ruangan maupun ditempatkan dalam lemari pendingin. Hal tersebut dikarenakan, jamur jenis ini memiliki kandungan air yang banyak sehingga jamur tiram ini sangat aktif melepaskan uap air dan menyebabkan jamur menjadi kering dan kantong penyimpanan menjadi basah karena uap air. Basahnya kantong penyimpanan, bisa menyebabkan jamur menjadi lebih cepat busuk dan tidak bisa digunakan kembali.

Tabel 4

Daya Simpan Jamur

\begin{tabular}{lc}
\hline \multicolumn{1}{c}{ Perlakuan } & $\begin{array}{c}\text { Rata- } \\
\text { Rata }\end{array}$ \\
\hline 100\% serbuk kayu & 28 \\
Serbuk kayu 85\% : dedak 15\% & 28 \\
Serbuk kayu 75\% : dedak 25\% & 28 \\
Serbuk kayu 65\% : dedak 35\% & 29 \\
Serbuk kayu 85\% : tepung tongkol & 29 \\
jagung 15\% & \\
$\begin{array}{l}\text { Serbuk kayu 75\% : tepung tongkol } \\
\text { jagung 15\% }\end{array}$ & 29 \\
$\begin{array}{l}\text { Serbuk kayu 65\% : tepung tongkol } \\
\text { jagung 35\% }\end{array}$ & 29 \\
\hline
\end{tabular}




\section{Kadar Protein}

Berdasarkan hasil analisis uji protein yang dilakukan di Balai Besar Perindustrian Hasil Perkebunan menunjukkan kadar protein yang berbeda- beda pada setiap perlakuan. Perlakuan pemberian tepung tongkol jagung dengan komposisi 25\% merupakan perlakuan yang memiliki kandungan protein tertinggi yaitu $20,9 \%$ sedang untuk pemberian dedak dengan komposisi 35\% yang memiliki kandungan protein yang tertinggi yaitu $15,5 \%$.

Tabel 5

Kadar Protein Jamur

\begin{tabular}{lc}
\hline \multicolumn{1}{c}{ Perlakuan } & $\begin{array}{c}\text { Rata- } \\
\text { Rata }\end{array}$ \\
\hline 100\% serbuk kayu & 13,1 \\
Serbuk kayu 85\% : dedak 15\% & 13,8 \\
Serbuk kayu 75\% : dedak 25\% & 15,0 \\
Serbuk kayu 65\% : dedak 35\% & 15,5 \\
Serbuk kayu 85\% : tepung tongkol & 20,4 \\
jagung 15\% & \\
$\begin{array}{l}\text { Serbuk kayu 75\% : tepung tongkol } \\
\text { jagung 15\% }\end{array}$ & 20,9 \\
$\begin{array}{l}\text { Serbuk kayu 65\% : tepung tongkol } \\
\text { jagung 35\% }\end{array}$ & 17,4 \\
\hline
\end{tabular}

Tingginya kadar protein pada penambahan tepung tongkol jagung dikarenakan didalam tongkol jagung mempunyai unsur kalium, vitamin, fosfor, dan nitrogen yang dapat meningkatkan kandungan protein pada jamur tiram putih. Rendahnya kadar protein pada media kontrol dikarenakan, dalam serbuk gergaji hanya memiliki selulosa $49 \%$, lignin $26,8 \%$, pentosan $15,6 \%$, karbon $50 \%$, hidrogen $6 \%$, nitrogen $0,10 \%$, abu 0,2\% (Narwanti, 2013), padahal pada pertumbuhan jamur tiram paling tidak kebutuhan pokok berupa N, P, K harus terpenuhi. Selain untuk memenuhi kebutuhan nutrisi pada jamur, unsur $\mathrm{N}$,
$\mathrm{P}, \mathrm{K}$ nantinya akan mempengaruhi tingi rendahnya kandungan nutrien pada jamur salah satunya berupa protein. Berbeda dengan penambahan tongkol jagung dan dedak akan saling melengkapi satu sama lain dalam memenuhi kebutuhan nutrisi jamur tiram putih.

\section{KESIMPULAN}

Berdasarkan hasil penelitian, maka dapat disimpulkan bahwa, tepung tongkol jagung dapat digunakan sebagai campuran atau pengganti dedak sebagai media tambahan dalam budidaya jamur tiram dan dapat meningkatkan pertumbuhan dan produksi jamur tiram. Komposisi yang tepat pada penggunaan tepung tongkol jagung adalah $75 \%$ serbuk kayu dan $25 \%$ tepung tongkol jagung.

\section{DAFTAR PUSTAKA}

Abdul, 2013. Karakteristik Pertumbuhan dan Produksi Jamur Tiram. Skripsi tidak diterbitkan. Pekanbaru: Fakultas Pertanian Universitas Riau.

Djarijah. 2010. Budidaya Jamur Tiram. Yogyakarta : Kanisius.

Gunawan. 2005. Perkembanganbiakan jamur tiram putih. On Line. http://perkembang-biakan-jamurtiram-putih.com/2005. Diakses tanggal 18 april 2015.

Murbandono. 2012. Studi Kelayakan Jamur Tiram Putih (Pleurotus ostreatus). EPP. Vol. 8. No.2. 2012: $48 \quad-56$. jurnalonline. itenas.ac.id/index.php /rekaintegra/ article/view/391. Diakses tanggal 3 Maret 2015. 
Narwanti. 2013. Kandungan Protein dalam Jamur Tiram. On Line. http://www. Kandungan-proteinjamur-tiram. html. Diakses tanggal 3 Maret 2015.

Sri Sumarsih. 2010. Untung Besar Usaha Jamur. Jakarta: Penebar Swadaya.

Suriawiria, H. 2010. Sukses Beragrobisnis Jamur Kayu, Shittake, Kuping, Tiram. Penebar Swadaya. Jakarta.

Tampubolon, J. 2010. Inventarisasi Jamur Makroskopis di Kawasan Ekowisata Bukit Lawang Kabupaten Langkat Sumatra Utara. Tesistidak diterbitkan. Medan: Universitas Sumatra Utara.

Welem. 2014. Cara Praktis Penyimpanan Jamur Tiram. On Line. http://www.vemale.com/kuliner/tips -dapur/8959-tips-menyimpanjamur-tiram. html. Diakses tanggal 3 Maret 2015. 